\title{
Flood frequency analysis by probability and stochastic method for Padma River, Bangladesh
}

\author{
Raihan Khan Opu ${ }^{1, ~}$, Abdullah Al Masum ${ }^{1}$, Ringkon Biswas ${ }^{1}$, Samiul Islam ${ }^{2}$ \\ ${ }^{1}$ Dept. of Civil Engineering, Rajshahi University of Engineering and Technology, Rajshahi 6204, Bangladesh \\ ${ }^{2}$ Junior Engineer BETS consulting services Ltd., Dhaka, Bangladesh
}

\section{Email address:}

raihan.ce08@gmail.com (R. K. Opu),masum24706@gmail.com (A. A. Masum),ringkon.biswas@gmail.com (R. Biswas), samiul_islam87@yahoo.com (S. Islam)

\section{To cite this article:}

Raihan Khan Opu, Abdullah Al Masum, Ringkon Biswas, Samiul Islam. Flood Frequency Analysis by Probability and Stochastic Method for Padma River, Bangladesh. American Journal of Civil Engineering. Vol. 2, No. 1, 2014, pp. 8-11.

doi: 10.11648/j.ajce.20140201.12

\begin{abstract}
In most of the practical cases, Flood frequency analysis is carried out due to the safe design of hydraulic structures. This paper represents the result of Flood frequency analysis for Padma River at Hardinge Bridge station. The Flood frequencies of 2, 5, 10, 20, 50, 100, 200, 300, 400, 500 and 1000 year Floods was analyzed by probability methods develop by Gumbel, Powell, Ven Te chow as well as Stochastic methods. The analysis was carried out for the duration of 13 years ranges from 2000 to 2012. This research aims to compare four methods of Flood frequency analysis to find the optimum method in terms of safe design of hydraulic structures. From the comparison between four methods the Gumbel and stochastic method may be recommended for designing and locating hydraulic structures.
\end{abstract}

Keywords: Flood frequency, Return period, Padma River, Standard Deviation, Skewness

\section{Introduction}

A Flood is an unusual high stage of a river due to runoff from rainfall and / or melting of snow in quantities too great to be confined in the normal water surface elevations of the river or stream, as the result of unusual meteorological combination [1].

Flood frequency analysis is an analytical technique that involves in the estimation of how often a specified event will occur. The analysis involves using observed annual peak flow data to calculate statistical information such as mean values, standard deviation, skewness and recurrence interval. Reliable flood frequency estimates are vital for floodplain management, to protection of public infrastructure; minimize flood related cost to government and private enterprises, for designing and locating hydraulic structures and assessing hazards related to the development of flood plains and epidemic control [2].

Bangladesh is one of the most flood prone countries in the world. Analysis indicates that about 21 percent of the country is subjected to annual flooding and an additional 42 percent is at risk of flood with varied intensity [3]. There are no taxonomic records of annual floods available in Bangladesh. The floods of 1954, 1955, 1974, 1987, 1988,
1998, 2004 and 2007 all caused enormous damages to properties and considerable loss of life. The floods of 1987, 1988, 1998, 2004 and 2007 flood caused heavy damage [4]. The exceptional flood of 1998 the most severe record in terms of both depth of inundation and duration, affect 69 percent of total land area. About half of the country was under water for upto 67 days with inundation depth reaching up to $3 \mathrm{~m}[4,5]$. Major factors contributing to such extreme devastation included lingering intensive rain in July and august 1998; simultaneously above danger flow levels of the Ganges, Brahmaputra and Meghna rivers [6]. This paper intent to estimate return periods associated with flood peaks of varying magnitudes from recorded floods using statistical methods as well as to compare four methods to find the methods that can be recommended for practical use for the safe design of hydraulic structures.

\section{Study Area}

The Padma is the name used in Bangladesh for a major trans-boundary river known in India as the main distributaries of the Ganges River that originates in the western Himalayas. Hardinge Bridge station whose Station ID SW90 of the Padma River is chosen as study area for 
research work. The Padma River is located in the North-Western part of the country and passed through Kushtia and Rajshahi district. Geographically it lies between $88^{\circ} 30^{\prime} 0^{\prime \prime}$ to $89^{\circ} 05^{\prime} 0^{\prime \prime}$ E longitude and $24^{\circ} 0^{\prime} 0^{\prime \prime}$ to $24^{\circ} 25^{\prime}$ $0 " \mathrm{~N}$ latitude. The catchment area of Padma is 46300 (Sq. $\mathrm{Km}$.) which is only $4.26 \%$ of total catchment area of Ganges [7]. This area has tropical monsoon climate where mean annual rainfall is $2000 \mathrm{~mm}$ which about $70 \%$ occurs during the monsoon season [8].

\section{Data Collection and Analysis}

Daily maximum discharge data (in $\mathrm{m} 3 / \mathrm{s}$ ) for 13 water years of record for SW90 gauging station on Padma River were obtained from Bangladesh Water Development Board (BWDB). The flow recording station was equipped with an automatic recorder. Annual peak discharge data are 52560.32, 53407.74, 40980.00, 59875.72, 37705.75, $43619.99, \quad 37254.92, \quad 54216.79, \quad 50562.31, \quad 38600.84$, 40275.58, 48684.80, 44275.29 cumecs. Data are ranging from 2000-2012 and gauging station is at Hardinge Bridge of Padma River.

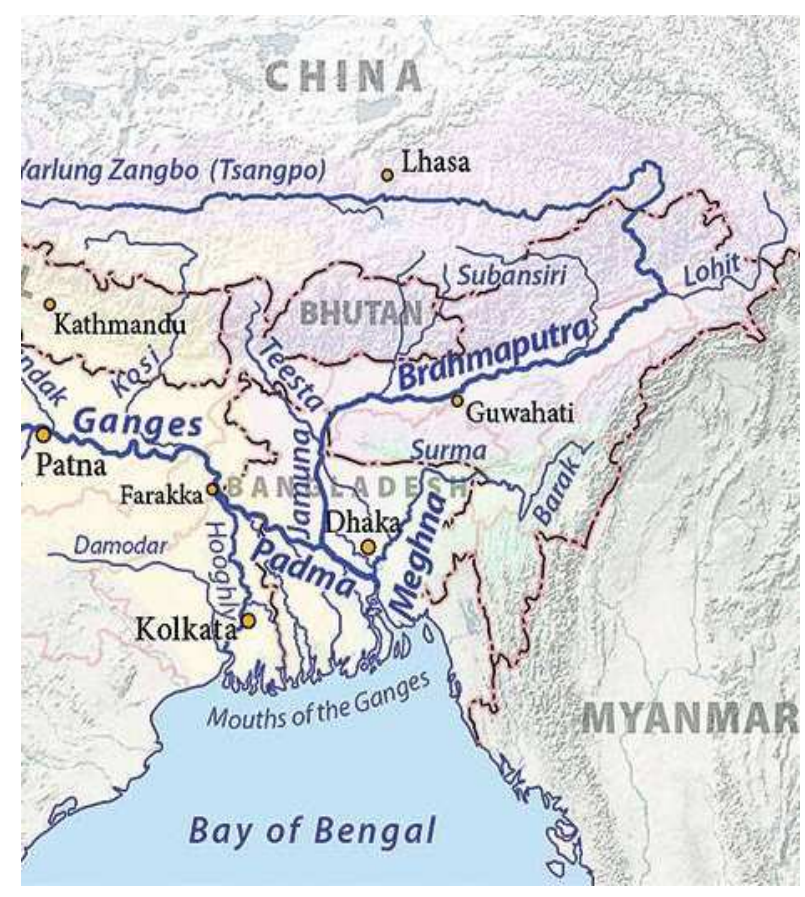

Figure 1. Location of Padma River

\section{Flood Frequency Method}

There are various methods to determine the flood frequencies such as Gumble, Powell, Ven Te chow and Stochasic methods. These methods have been used for the analysis of Padma River.

\subsection{Gumble Method}

According to the extreme value distribution, the probability of occurrence of the flood peak $\geq Q$ is given by

$$
P=1-e^{-e^{-y}}
$$

The reduce variety y is given by

$$
y=-0.834-2.303 \log \log \frac{T}{T-1}
$$

or

$$
y=-0.834-2.303 X_{T}
$$

Where,

$$
X_{T}=\log \log \frac{T}{T-1}
$$

The reduce variety $y$ is linear with the variate $Q$ (annual flood peak) itself and is given by

$$
y=\sigma_{n}\left(\frac{Q-\bar{Q}}{\sigma}\right)+\bar{y}_{n}
$$

Where $\sigma_{n}$ (reduce standard deviation) and $y_{n}$ (reduced mean) are function of the sample size $\mathrm{n}$ and are taken form table 7.3 [9].

Now

$$
Q_{T}=\bar{Q}+\left(\frac{y-\overline{y_{n}}}{\sigma_{n}}\right) \sigma
$$

Or

$$
Q_{T}=\bar{Q}+k \sigma
$$

Where the frequency factor, $k=\left(\frac{y-\overline{y_{n}}}{\sigma_{n}}\right)$ and

$Q_{T}=$ annual flood peak which has a recurrence interval $T$.

\subsection{Powell's Method}

A modification in the value of $k$ by Gumbel's method was made by R. W. Powell (1943)

$$
k=-\frac{\sqrt{\sigma}}{\pi}\left[\gamma+\ln \ln \frac{T}{T-1}\right]
$$

Where,

Euler's constant, $\gamma=0.5772$

Simplifying, $k=-1.1-1.795 X_{T}$

$$
\text { Then } Q_{T}=\bar{Q}+k \sigma
$$

\subsection{Ven Te Chow Method}

Another modification of the Gumbel's method was made 
by Ven Te Chow by using the frequency factor. The equation is

$$
Q_{T}=a+b X_{T}
$$

Where, $X_{T}=\log \log \frac{T}{T-1}$

Where,

$\mathrm{a}, \mathrm{b}=$ Parameters estimated by the method of moments from the observed data.

The following equations are derived from the method of least squares.

$$
\begin{gathered}
\sum Q=a n+b \sum X_{T} \\
\sum\left(Q X_{T}\right)=a \sum X_{T}+b \sum\left(X_{T}^{2}\right)
\end{gathered}
$$

From which $\mathrm{a}$ and $\mathrm{b}$ can be solved.

In this method a plotting position has been assigned for each value of $\mathrm{Q}$ when arranged in the descending order or magnitude of flood peaks. For example if an annual flood peak $\mathrm{Q}_{\mathrm{T}}$ has a rank $\mathrm{m}$, it's plotting position

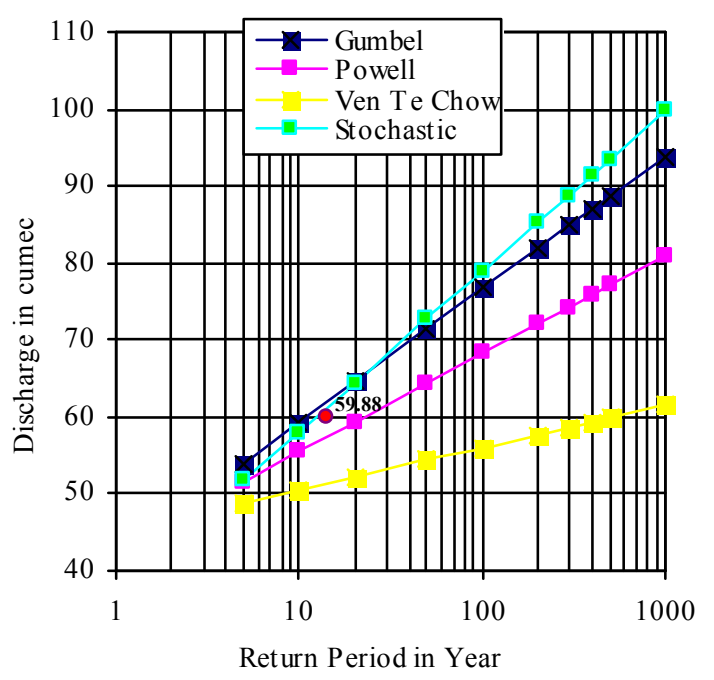

Figure 2. Flood frequency curve of Padma River

$$
\begin{gathered}
T=\frac{n+1}{m} \\
X_{T}=\log \log \frac{n+1}{n+1-m}
\end{gathered}
$$

\subsection{Stochastic Method}

By this method the annul flood peak $\mathrm{Q}_{\mathrm{T}}$

$$
Q_{T}=Q_{\min }+2.3\left(\bar{Q}-Q_{\min }\right) \log \left(\frac{n_{f}}{n} . T\right)
$$

Where, $T=\frac{n}{m}$

$n_{f}=$ number of recorded floods, counting only one for the same flood peak occurring in different years.

\section{Results and Discussions}

The highest measured discharge of 59875.72 cumecs was recorded in year 2003 and lowest discharge of 439.83 cumecs was recorded in year 2010 for Padma River at station Hardinge Bridge.

For Gumbel method, $\mathrm{Q}=46309.19, \sigma=7367.616, \overline{\mathrm{y}}_{\mathrm{n}}=$ 0.50576 and $\sigma_{\mathrm{n}}=0.99064$

For Powell method, $Q=46309.19, \sigma=7367.616$

For Ven Te Chow Method, $\Sigma \mathrm{Q}=603030, \Sigma \mathrm{X}_{\mathrm{T}}=-7.57096$, $\Sigma \mathrm{QX}_{\mathrm{T}}=-363977, \Sigma \mathrm{X}_{\mathrm{T}}^{2}=6.8471$ and from method of moments, $\mathrm{a}=43.12$ and $\mathrm{b}=-5.48$

For Stochastic method, $\bar{Q}=46309.19, \mathrm{Q}_{\min }=37254.32$ and $\mathrm{n}_{\mathrm{f}}=\mathrm{n}=13$

Table 2. Flood corresponding to return period in 1000 cumecs

\begin{tabular}{cccccc}
\hline $\begin{array}{c}\text { Return Period } \\
\text { T }\end{array}$ & Gumbel & Powell & $\begin{array}{c}\text { Ven Te } \\
\text { Chow }\end{array}$ & $\begin{array}{c}\text { Stochastic } \\
\text { Method }\end{array}$ & $\begin{array}{c}\text { Probability } \\
\text { P=1/T (\%) }\end{array}$ \\
\hline 2 & 45.28 & 45.16 & 45.97 & 43.52 & 0.10 \\
5 & 53.71 & 51.34 & 48.67 & 51.81 & 0.20 \\
10 & 59.29 & 55.44 & 50.46 & 58.08 & 0.25 \\
20 & 64.64 & 59.36 & 52.17 & 64.36 & 0.33 \\
50 & 71.57 & 64.45 & 54.39 & 72.65 & 0.50 \\
100 & 76.77 & 68.26 & 56.05 & 78.92 & 1.00 \\
200 & 81.94 & 72.06 & 57.7 & 85.19 & 2.00 \\
300 & 84.96 & 74.27 & 58.67 & 88.86 & 5.00 \\
400 & 87.11 & 75.84 & 59.36 & 91.47 & 10.00 \\
500 & 88.77 & 77.06 & 59.89 & 93.49 & 20.00 \\
1000 & 93.93 & 80.85 & 61.54 & 99.76 & 50.00 \\
\hline
\end{tabular}

The flood frequency curves by the above four methods have been plotted on semi-log paper (figure 2).

\section{Conclusions}

For flood frequency analysis, 13 years of annual peak flood readings of Padma River at Hardinge bridge station was used. For analysis four methods were used: Gumbel method, Powell method, Ven Te chow method as well as Stochastic method. From the table 100 year flood given by Gumbel method is 76770 cumecs, 68260 cumecs by Powell method, 56050 cumecs by Ven Te Chow method and 78920 
cumecs by Stochastic method. It can be seen that the highest annual flood peak 59875.72 cumecs (indicated by red dot in figure 2) during a period of 13 years $\mathrm{T}=(13+1) / 1=14$ year has exceeded the 20 year flood given by Powell and Ven Te chow method. Hence Powell and Ven Te Chow method cannot be used for the safe design of a hydraulic structure. So Gumbel and Stochastic method gives the most probable maximum flood in the life period of structure. However in this study, the Gumbel and Stochastic method using annual flood data give safe design values.

\section{References}

[1] H.M Raghunath, 2009 revised edition, Hydrology: principle analysis and design, New Delhi, New age international publishers.

[2] Tumbare, M. J. 2000. "Mitigating Flood in South Africa", paper at the $1^{\text {st }}$ WARSFA/ water Net Symposium: suntainable use of water Resources, 1-2 November, Maputo

[3] Ahmed, A.U and Mirza, M. M. Q. 2000. "Review of causes and Dimensions of Floods with Particular Reference to
Flood' 98: National Perspectives". In Ahmed, Q.K., Chowdhury, Press Limited, Dhaka, pp. 67-84.

[4] Bangladesh Water Development Board (BWDB), 2012. Annual Flood Report 2012, Flood Forecasting \& Warning Centre Processing \& Flood Forecasting Circle, Bangladesh Water Development Board.

[5] Islam KMN, and Mechler R. 2007. ORCHID: Piloting Climate Risk Screening in DFID Bangladesh. An Economic and Cost Benefit Analysis of Adaptation Options. Institute of Development Studies, University of Sussex, UK.

[6] Economics of Adaption to Climate Change Bangladesh 2010. The World Bank Group, Washington, D.C. 20433 USA

[7] Catchment areas of major rivers : http://www.jrcb.gov.bd/basin_map.html ( Accessed $5^{\text {th }}$ January, 2014)

[8] Hassan S. and Akhtaruzzaman A.F.M 2010. "Environmental Change Detection of the Padma river in the North-Western part of Bangladesh using Multi-date Landsat Data" ICEAB10, Japan, Sept. 2010

[9] K. Sunbaranya, 2011 Eleventh reprint, Engineering hydrology, New Delhi, Tata McGraw Hill Education Private Limited. 